\title{
Polymorphism of $\beta$-Lactoglobulin Gene and their Effects on Milk Traits in Friesian X Bunaji Cattle
}

\author{
Gabche A. E. Epse Laisin., Adedibu I. I., Kabir M., Iyiola-Tunji A.O
}

\begin{abstract}
The dairy cattle breeding programs have been focused on the use of molecular genetics techniques to identify specific DNA markers that associate with economically important traits; these markers have been used to supplement conventional breeding methods and has resulted in the selection of young animals for future breeding stock as well as enhanced production. The present study was designed to identify the most common genetic variants of beta lactoglobulin gene and assess their significant effects on milk traits in Friesian $X$ Buanji cows. The polymorphism of $\beta$-lactoglobulin geneswas detected via Matrix-assisted laser desorption/ionization time of flight mass spectrometry (MALDI-TOF) in 30 Friesian $X$ Bunaji cows. Two SNPs LGB_64 and LGB_118 at position 103303475 and 103304757 of the beta-lactoglobulin gene locus were genotyped. The results of this study revealed that the 30 Friesian $X$ Bunaji cows were polymorphic and had two alleles $A$ and $B$ with frequencies of 68.3 and 31.7 percent respectively; allele $B$ occurred more frequent than $\mathrm{A}$. In addition, three genotypes homozygote $\mathrm{AA}(2$ cows), heterozygote $\mathrm{AB}$ (15 cows), and homozygote BB (13 cows) were found with frequencies of 6.7 , 50.0 and 43.3 percent respectively. The most frequent genotype was $A B(50.0$ percent) followed by $B B(43.3$ percent), while the least common was AA (6.9 percent). Furthermore, the $\beta$-LG genotypes $(\mathrm{AA}, \mathrm{AB}$, and $\mathrm{BB})$ significantly affected daily milk yield $(\mathrm{P}<0.01)$, and content of milk fat $(\mathrm{P}<0.05)$. It might be concluded that in the Friesian X Bunaji cows the $\beta$-lactoglobulin may be documented as genetic marker in selection programs to enhanced milk production traits in dairy cattle.
\end{abstract}

Index Terms - Genetic polymorphism, $\beta$-lactoglobulin gene, Friesian X Bunaji cow, Milk traits.

\section{INTRODUCTION}

Currently, the dairy cattle breeding programs are focused on the use of molecular genetics techniques to identify specific DNA markers that associate with economically important traits and this has resulted in the selection of young animals for future breeding stock [1]. Molecular marker is defined as a fragment of DNA sequence related to specific region of the genome of an individual [2] and are inherited according to Mendel's laws [3]. Genetic markers research is focused on investigating mutations situatedwithin genes and associating them with economically important production traits [4]. Several molecular techniques have been established to identify alleles and genotypes frequencies within milk protein genes in cattle [5].The iPlex massARRAY genotyping

Gabche A. E. Epse Laisin., ,Department of Animal Science, Ahmadu Bello University, Zaria, Kaduna State, Nigeria.

Adedibu I. I., Department of Animal Science, Ahmadu Bello University, Zaria, Kaduna State, Nigeria.

Kabir M., Department of Animal Science, Ahmadu Bello University, Zaria, Kaduna State, Nigeria.

Iyiola-Tunji A.O, National Agricultural Extension and Research Liaison Services (NAERLS) Ahmadu Bello University, Zaria technique is one of the techniques that takes advantage of polymorphism detected at the DNA level regardless of age, physiological status, and sex of the animal [3].

Cow milk contains all the nutrients that neonatal animals require for energy, growth, development, and repair of tissues and is a major raw material for human $\operatorname{diet}[6,7]$. Globally, about 13 percent of protein requirement of individual persons is gotten from milk and dairy products [8]. In Africa, dairy production and marketing contribute to the livelihoods of over one billion rural farmers through improved food and income security $[9,10]$.

The protein fraction of bovine milk contains about 95 percent of six major milk proteins: four caseins (alpha ${ }_{\mathrm{S} 1}$-casein $(\alpha \mathrm{s} 1-\mathrm{CN})$, beta-casein $(\beta-\mathrm{CN})$, alpha $\mathrm{s}_{2}$-casein $(\alpha \mathrm{s} 2-\mathrm{CN})$, kappa-casein $(\kappa-\mathrm{CN})$ and two whey proteins: $\alpha$-lactalbumin $(\alpha$-LA) and $\beta$-lactoglobulin $(\beta$-LG) (11). Beta-Lactoglobulinmakes up approximately 10 percent of the total milk protein and contains about 50 percent of the total whey protein $(14,15,16]$. The primary structure of $\beta$-LG was established by Braunitzer et al. (17) and its reference protein is $\beta$-LG $\mathrm{B}$ and it contains 162 amino acids residues with a molecular weight of 18,277 Daltons and is coded by the $L G B$ gene[14, 15]. The $L G B$ gene is mapped on bovine chromosome 11 , it spans $4.7 \mathrm{~Kb}$ and is organised in seven small exons and six introns. Polymorphism of B-LG gene was established in 1955 by Aschaffenberg and Drewry [18]. Up to date, 12 genetic variants of $\beta$-lactoglobulin ( $\beta$-LG) have been discovered that include: A, B, C, D, Dr, E, F, G, H, I, J and $\mathrm{W}(14,19,20)$.However, in the dairy cattle, the most frequent genetic variants are $\mathrm{A}$ and $\mathrm{B}(8,21)$. Variant $\mathrm{A}$ differs from B by two-point mutation that involves amino acid replacements at position 64 where variant B has Glycine

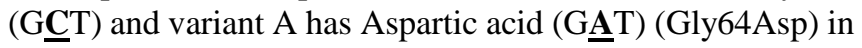
the mobile surface loop (CD) and at position 118 where

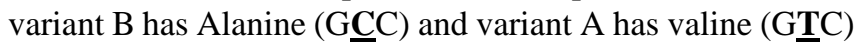
(Ala118Val) in the hydrophobic core $(8,12,22)$. In addition, variant $A$ has a higher protein concentration compared to variant B (8); this difference is attributed to diverse levels of expression of the A and B variants (23). Several studies have been carried out to detect the polymorphisms of beta-lactoglobulin $(\beta-L G)$ and their relationship with milk production traits, and processing properties [24, 25]. The resultshave been inconsistent; some studies confirmed significant association[26] while others have not [27, 28) therefore, more studies are required for precise situations. However, reasons for the disparities in the results might be due to non-additive interaction of alleles from various loci, or the interaction of genotypes with environmental factors (29).

In Nigeria, one of the strategies to enhancedomestic milk production on dairy cattle farms is through crossbreeding 
schemes between the indigenous and the exotic breeds; Friesian sires and their semen are among the key dairy breed of cattle used in cross breeding of the Bunaji cows [30]. Additionally, crossbreeding combines disease resistance, the hardiness and adaptability of the indigenous cattle with the early sexual maturity and high milk yield of European dairy breeds [31].

Considering that Friesian X Bunaji cattle is one of common dairy cattle breeds in Nigeria and the role of B-LG gene in milk related traits, this study was designed to detect $\beta-L G$ gene polymorphisms and the influence of the variants on milk traits in Friesian X Bunaji cows.

\section{MATERIAL AND METHODS}

A. Location of the Experiment: The study was accomplished at the Dairy Research Programme farm of the National Animal Production Research Institute (NAPRI), Ahmadu Bello University (ABU), Shika, Zaria, Kaduna State, Nigeria. Shika is in the Northern Guinea Savanna between latitude $11^{\circ} 12^{\prime} 59^{\prime}$ ' $\mathrm{N}$ and longitude $07^{\circ} 33^{\prime} 40^{\prime}$ ' $\mathrm{E}$ at an elevation of $702 \mathrm{~m}$ above sea level (32). The average annual rainfall is $1,100 \mathrm{~m}$ (May to October). Dry, cool weather harmattan (mid-October to January) and dry season (February-May).

B. Ethical Statement:The study was realizedbased on an approved guideline by the Ahmadu Bello University (ABU) Committee on Animal Use and Care (ABUCAUC), Zaria, Nigeria.

C. Experimental Animals and Management:Thirty (30) Friesian X Bunaji cows reared at Dairy farm of NAPRI were used for this study. Thecows were kept under semi-intensive system and fed on the same diet. They were allowed to graze on paddocks of established pasture consisting of assorted grasses [33]. In the dry season, hay, silage, and cotton seed cake were offered to the cows. Furthermore, the cows had access to fresh water and mineral salt blocks ad-libitum. Milking was done twice daily with a milking machine. Each cow was given about $2.0 \mathrm{kgs}$ of concentrate feed at each milking. The cows were controlled against ectoparasites weekly in the dry season and twice a week during the rainy season.

D. Collection of Blood Sample:Five (5) $\mathrm{ml}$ of blood samples were collected from 30 Friesian X Bunaji cowsviatheir jugular veinwith sterile needle and syringe and put in test tubes containing an anticoagulant (EDTA). The blood wastransported in an ice bag to a laboratory (Bioinformatics Services) at Ibadan, Oyo State, Nigeria; on arrivalthe samples were stored at $4{ }^{\circ} \mathrm{C}$ awaiting the extraction of the genomic DNA (gDNA).

E. Genomic DNA extraction and quantification: Genomic DNA was extracted from $5 \mathrm{ml}$ of whole blood of 30 cows using a QUICK-DNA MINIPREP KIT Cat No. D3024 (Manufactured by Zymo Research) and the manufacturer's protocol were followed. The purity and quality of each extractedgDNA was evaluatedthrough a Nanodrop Spectrophotometer; protein contamination was assessedvia the ratio of absorbance at $260 \mathrm{~nm}$ and $280 \mathrm{~nm}$. Additionally,gel electrophoresis was used to measure the integrity of the extracted gDNA. The samples that showed an optical density (OD) ratio $(260 \mathrm{~nm} / 280 \mathrm{~nm})$ ranging from 1.8 to 2.2 were kept for further analyses. The 30 samples of gDNA were forwarded to Inqaba Biotec West Africa Ltd for SNPs genotyping.

\section{F. SNPs Genotyping Sequenom MassARRAY® system (iPLEX GOLD Technique):}

Two non-synonymous missense SNPs $L G B \_64$, and $L G B$ _118 documented by Ketto et al. (35) and 30 gDNA belonging to Friesian X Bunaji cows were genotyped via the MassArray genotyping platform the Sequenom MassARRAY® system (iPLEX GOLD; Sequenom, San Diego, CA, USA) following manufacturer's protocols. The method is based on the analysis of DNA products using matrix-assisted laser desorption ionization time-of-flight (MALDI-TOF) mass spectrometry (MS) [34].

The PCR amplification of the targeted region of gDNA comprisingof the SNPs was attainedin a $5 \mu$ l total volume of reaction system containing $20 \mathrm{ng}$ of genomic DNA, $0.5 \mu \mathrm{l}$ $10 \times$ PCR buffer, 0.5U HotstarTaq (Qiagen), 0.5 pmol of each primer, and $0.1 \mu \mathrm{l}$ dNTPs. PCR reactions were achieved in a PTC-100 PCR instrument (Eppendorf) under the following conditions: 4 minutes of denaturation at $94^{\circ} \mathrm{C}, 35$ cycles of 20 seconds at $94^{\circ} \mathrm{C}, 30$ seconds at $56^{\circ} \mathrm{C}$ and 1 minute at $72^{\circ} \mathrm{C}$ and a final extension at $72^{\circ} \mathrm{C}$ for 3 minutes. After which, $2 \mu \mathrm{l}$ shrimp Alkaline Phosphatase (SAP) (SEQUENOM) was used to clean the PCR products. The single base extension used $2 \mu \mathrm{l}$ EXTEND Mix (SEQUENOM) consisting of $0.94 \mu \mathrm{l}$ Extend primer Mix, $0.2 \mu \mathrm{l}$ iPLEX termination mix, and $0.041 \mu \mathrm{l}$ iPLEX enzyme and was realized via the following steps: initial denaturation at $94^{\circ} \mathrm{C}$ for 30 seconds, followed by 40 cycles of three steps amplification profile of 5 seconds at $94^{\circ} \mathrm{C}$, additional 5 cycles of 5 seconds at $52^{\circ} \mathrm{C}$ and 5 seconds at $80^{\circ} \mathrm{C}$ and a final extension at $72^{\circ} \mathrm{C}$ for 3 minutes. The PCR products were cleaned with resin purification and werethen analysed via MassARRAY Analyzer Compac (SEQUENOM) and software TYPER (SEQUENOM). Table 1 , represents the marker IDs, primer IDs and their sequences adapted from previous publication (35).

Table 1. Single nucleotide (SNIP ID) polymorphism of beta lactoglobulin gene and primer sequences for the genotyped markers

\begin{tabular}{|l|l|l|l|l|}
\hline SNP ID & Position (bp) & Forward primer sequence & Reverse primer sequence & $\begin{array}{l}\text { Extended } \\
\text { sequence }\end{array}$ \\
\hline LGB_64 & 103303475 & $\begin{array}{l}\text { ACGTTGGATGGCAATG } \\
\text { ATCTTCTTCTGAGC }\end{array}$ & $\begin{array}{l}\text { ACGTTGGATGATGAAA } \\
\text { ATGGTCCATGCCCG }\end{array}$ & GTCTTTCAGGGA \\
GGAACG \\
ACGTTGGATGTGCTCTT & $\begin{array}{l}\text { ACGTTGGATGAGGACC } \\
\text { ACCCACCCAGGC } \\
\text { CTGCATGGAGAAC }\end{array}$ & ACACAGCTGGTCTC & ACTGGCAG \\
\hline
\end{tabular}

Source: Ketto et al. [35] 
2.7Collection of Milk Samples: Twenty millilitres (20) of milk were collected once from one of the morning milks of each of the 30 Friesian X Bunaji cows for analysis of milk traits (two duplicates). Additionally, data on each cow's parity (1, 2-3 and $\geq 4)$ and lactation stage (early (7- 90 days), mid (91-180 days) and late (181-305 days) were collected. Moreover, the average daily milk yield of each cow was calculated from the farm records.

2.8 Laboratory Analysis of Milk Samples: Twenty millilitres $(20 \mathrm{ml})$ of milk were collected from each cow, frozen at $4^{\circ} \mathrm{C}$ and transported in an ice bag to the laboratory at Centre of Excellence in Agriculture Development and Sustainable Environment (CEADESE) Central Laboratory, Federal University of Agriculture, Abeokuta, Nigeria. The 20 $\mathrm{ml}$ of milk from each cow was used for duplicates analysis of contents of salts, fat, protein, lactose, solid-not-fat (SNF), and $\mathrm{pH}$ usingLactoscan milk Analyzer. The total solid (TS) was then estimated via the formula:

$\%$ Total solid $=\%$ SNF $+\%$ Fat

2.9. Statistical analyses: The effects of beta lactoglobulin genotypes on the milk yield and composition traits were analysed by using the MIXED procedure of Statistical Analysis System (SAS), Version 9.0 (SAS, [36], where the effect of cow was treated as a random effect and that of lactation stage, parity, and genotype were considered as fixed effects. However, the effects of lactation stage and parity were found to be non-significant and consequently, omitted from further statistical analysis. The fixed effects of the beta lactoglobulin genotypes on the milk yield and composition traits were tested in model 1 :

$Y_{i j k}=\mu+\beta L G g e n_{i}+\operatorname{Cow}_{j}+\varepsilon_{i j k}$

Where:
$\mathrm{Y}_{\mathrm{ijk}}=$ dependent variables include milk yield and composition traits;

$\mu=$ the overall mean;

$\beta L G g e n_{i}=$ the fixed effect of $\mathrm{i}^{\text {th }} \beta-L G$ genotype (i=AA or AB or BB)

$\mathrm{Cow}_{\mathrm{j}}=$ the random effect of $\mathrm{j}^{\mathrm{th}} \operatorname{cow}(\mathrm{j}=1$ to 30$) \mathrm{N} \sim\left(0, \sigma_{\text {cow }}^{2}\right)$, $\varepsilon_{\mathrm{ijk}}=$ the random residual effect $\mathrm{N} \sim\left(0, \sigma_{\varepsilon}^{2}\right)$.

Furthermore, the values were presented as least squares means and their differences were tested using Tukey-Kramer procedure of SAS [36], which adjusted tests forunequal subgroup size and multiple comparison at $\mathrm{p} \leq 0.05$ and $\mathrm{p} \leq 0.01$ levels as described in Kramer (37). In addition, the differences between the least squares means for each fixed effect were tested with the Probability of Difference (PDIFF) option of the mixed procedure of SAS.

\section{RESULTS AND DISCUSSIONS}

A. iPlex MassARRAY results for two SNPs genotyped at beta lactoglobulin gene locus

In the current study Matrix-assisted laser desorption/ionization, time-of-flight mass spectrometry (MALDI-TOF MS) mass spectra plotted allelic peak intensity (y-axis) against mass (Daltons) ( $x$-axis). After which, the MassARRAY Typer software analysed the allele peak intensities and generated cluster plots that showed genotype calls at the SNP LGB_64locus (Plate 1a -d), and SNP $L G B \_118$ locus (Plate 2a-d) of the 30 Friesian X Bunaji cows.

At the SNP LGB_64 locus: The results of this study indicated that the SNP LGB_64 locus was polymorphic and had two alleles $A$ and $G$ that determined the genetic variants A and B respectively. Three genotypes AA (2 cows), AG (15 cows) and GG (13 cows) were determined from the allele's peak intensities corresponding to genetic variants $\mathrm{AA}, \mathrm{AB}$, and BB respectively (Plate 1a-d).

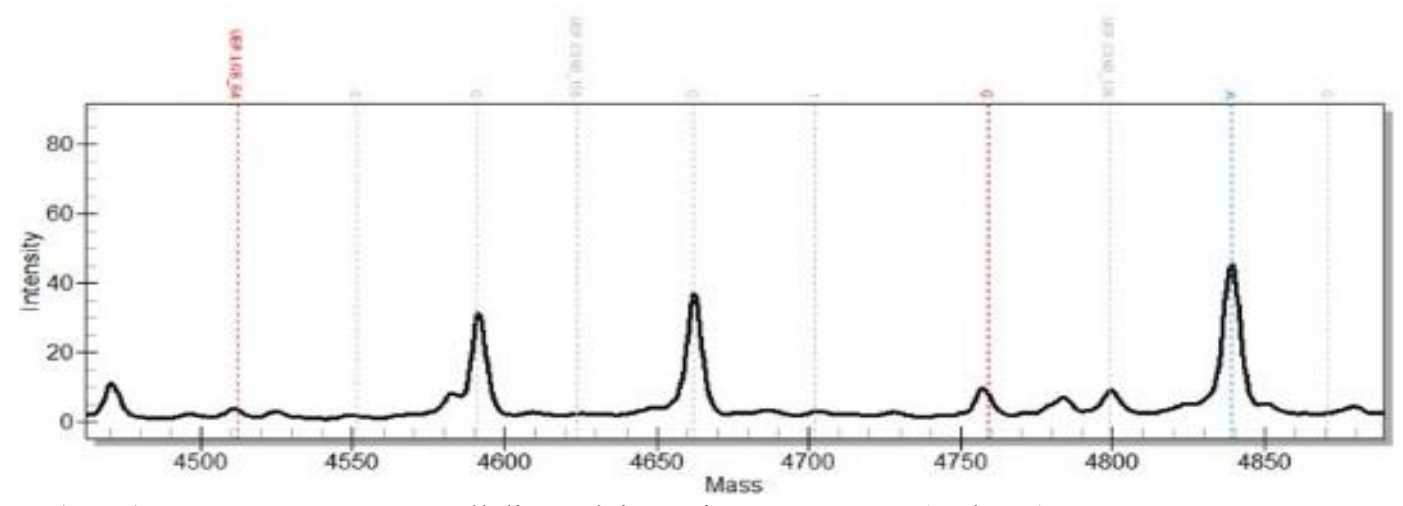

Plate 1a. MassARRAY spectrum plotting of allelic peak intensity versus mass (Daltons) indicated homozygosity of allele A at 4840 Da corresponding to genetic variant A at the SNP LGB_64 locus in 30 Friesian X Bunaji cows. 


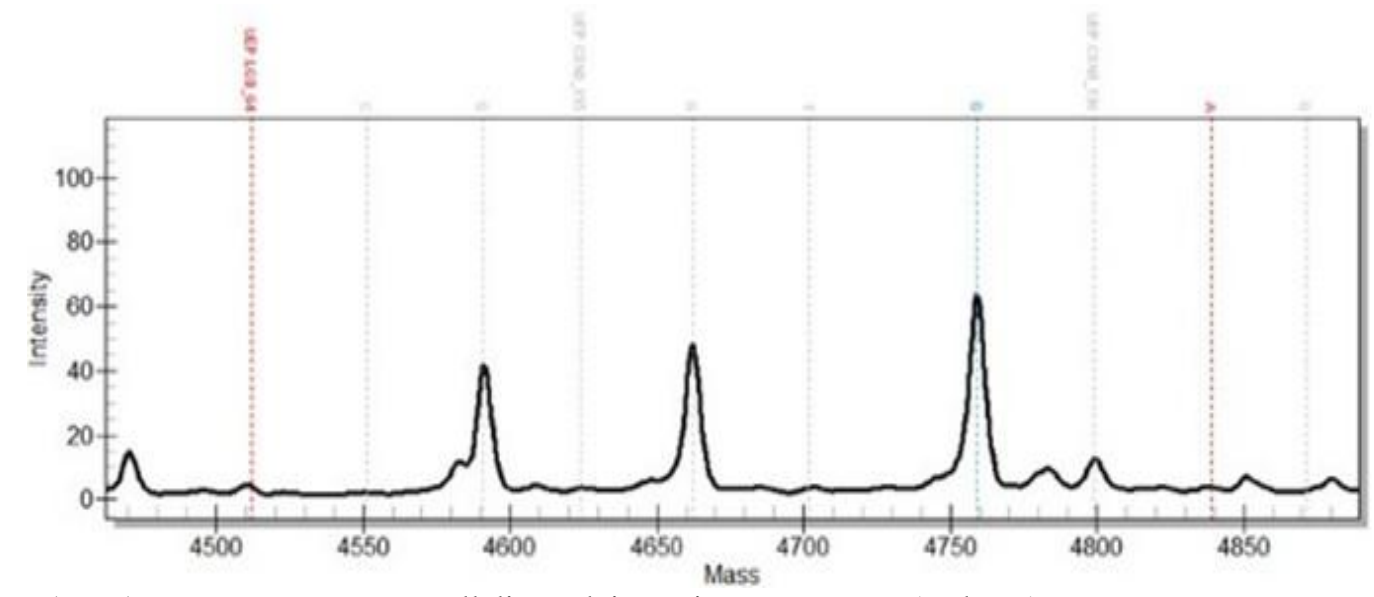

Plate 1b. MassARRAY spectrum plotting of allelic peak intensity versus mass (Daltons) indicated homozygosity of allele $\mathrm{G}$ at 4760 Da corresponding to genetic variant B at the SNP LGB_64 locus in 30 Friesian X Bunaji cows.

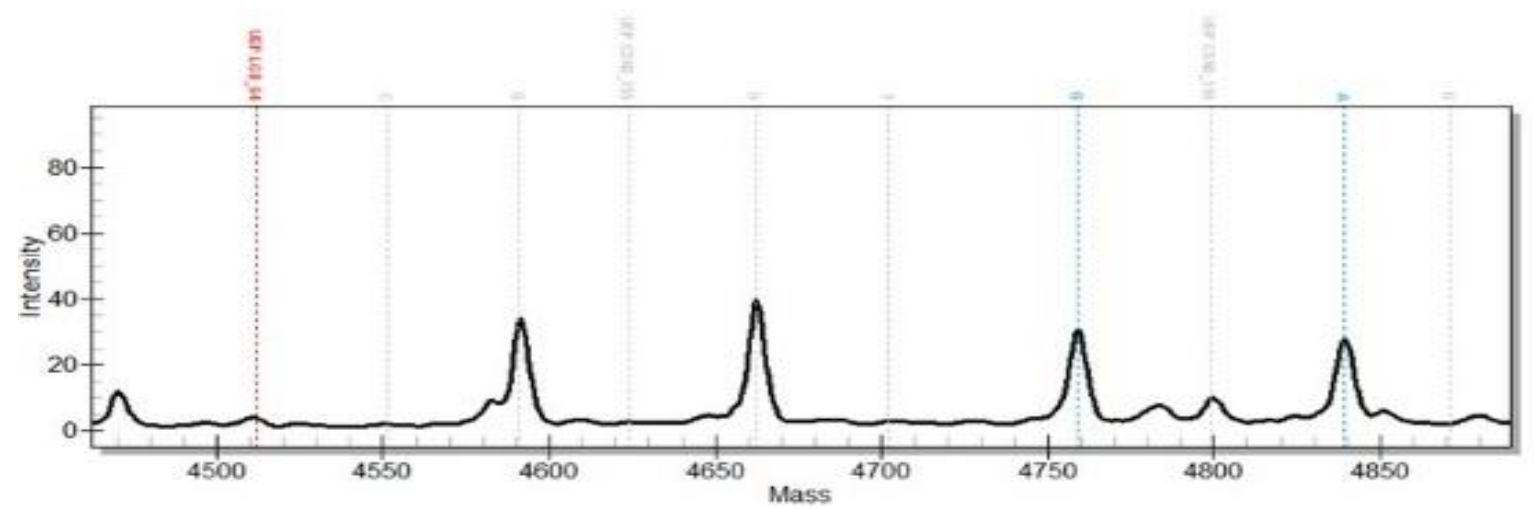

Plate 1c. MassARRAY spectrum plotting of allelic peak intensity versus mass (Daltons) indicated heterozygosity of allele $\mathrm{G}$ at 4760 $\mathrm{Da}$ and allele A at4840 Da corresponding to genetic variants B and A respectively at the SNP LGB_64locusin 30 Friesian X Bunaji cows.

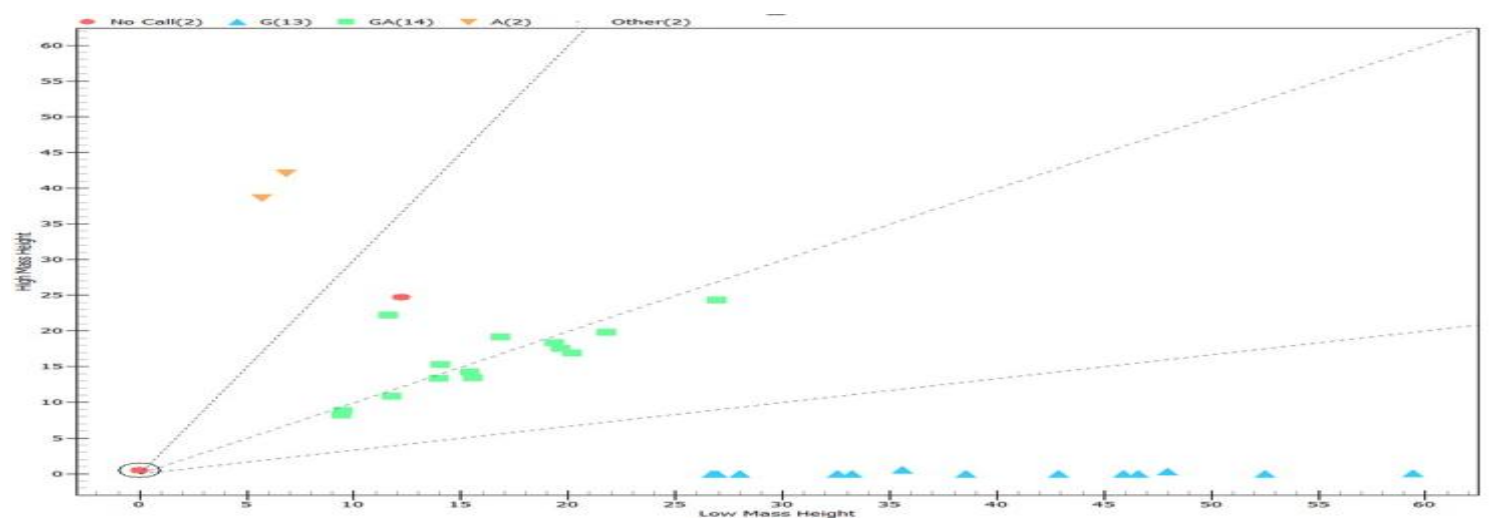

Plate 1d. The cluster plot indicated three genotypes of AA ( 2 cows), AG (14 cows) and GG (13 cows) corresponding to genetic variants $\mathrm{AA}, \mathrm{AB}$, and $\mathrm{BB}$ respectively at the SNP $L G B \_64$ locus in 30 Friesian X Bunaji cows.

At the SNP LGB_118 locus: The results of this study indicated that the SNP LGB_118 locus was polymorphic and had two alleles $\mathrm{T}$ and $\mathrm{C}$ that determine genetic variants $\mathrm{A}$ and $\mathrm{B}$ respectively. Three genotypes TT (2 cows), CT (15 cows) and CC (13 cows) were determined from the allele's peak intensities corresponding to genetic variants $\mathrm{AA}, \mathrm{AB}$, and $\mathrm{BB}$ respectively (Plate

$$
\text { 1a-d) }
$$




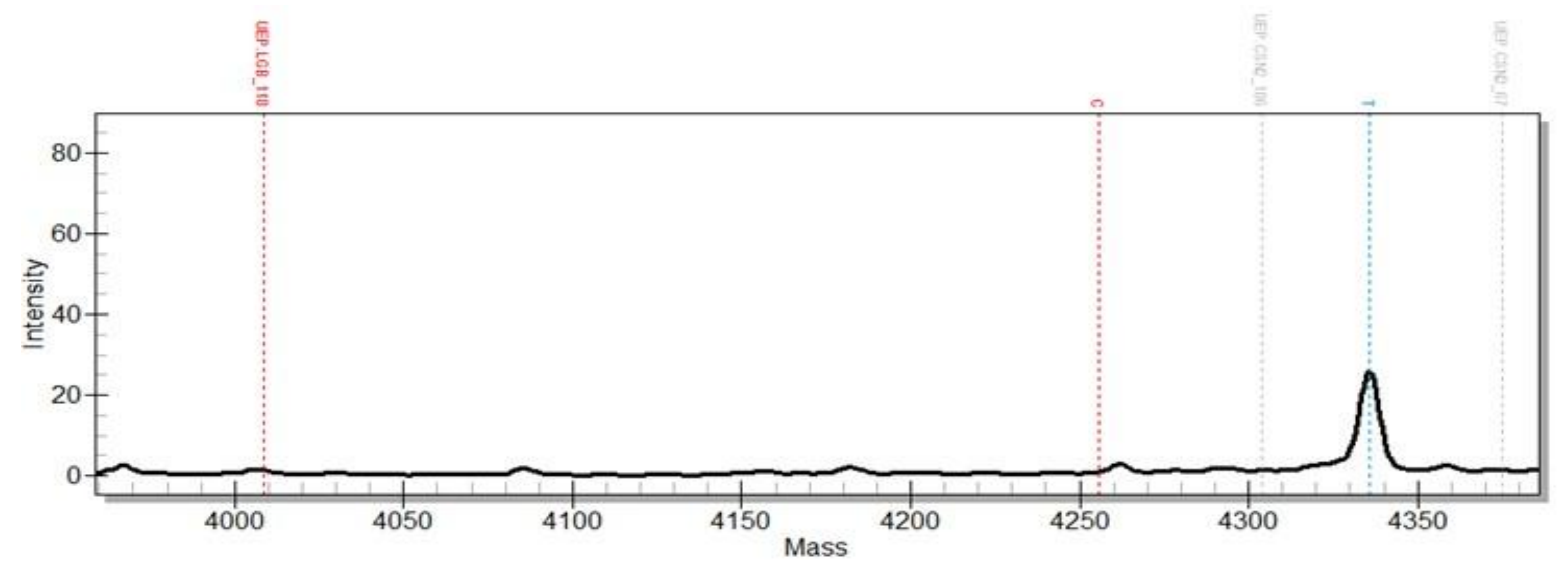

Plate 1a. MassARRAY spectrum plotting of allelic peak intensity versus mass (Daltons)showed homozygosity of allele T at $4335 \mathrm{Da}$ corresponding to genetic variant Aat the SNP LGB_118 locus in 30 Friesian X Bunaji cows.

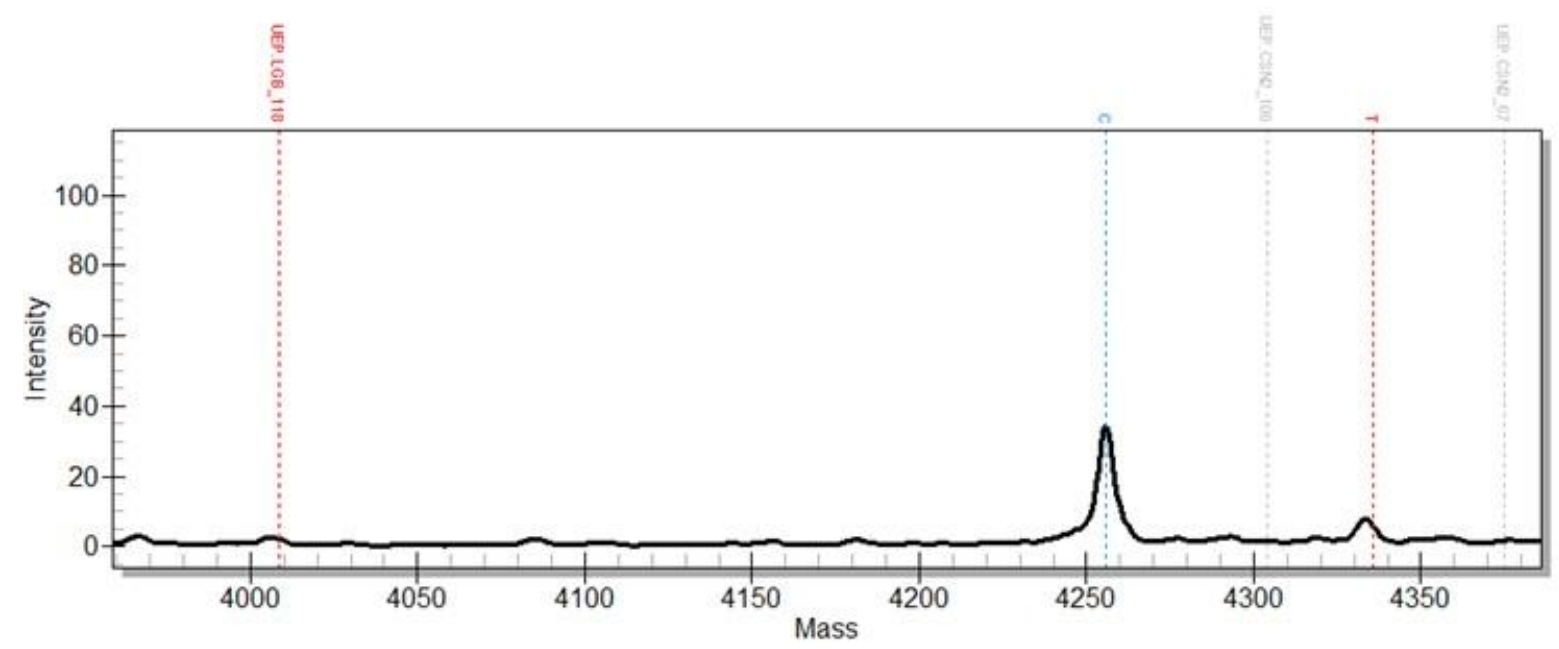

Plate 1b. MassARRAY spectrum plotting of allelic peak intensity versus mass (Daltons) indicating homozygosity of allele $\mathrm{C}$ at 4255 Da corresponding to genetic variant B the SNP LGB_118locus in 30 Friesian X Bunaji cows.

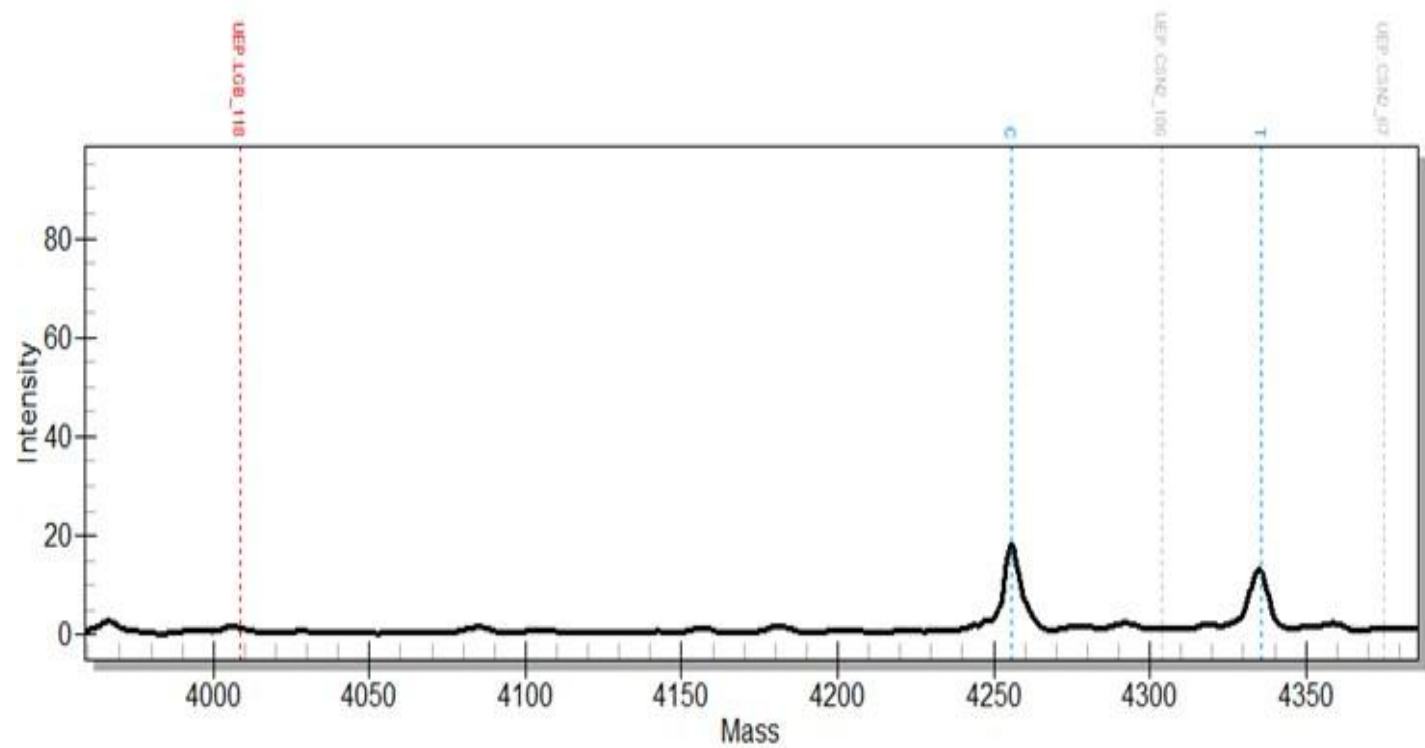

Plate 1c. MassARRAY spectrum plotting of allelic peak intensity versus mass (Daltons) indicated heterozygosity of allele $\mathrm{C}$ at 4255 $\mathrm{Da}$ and allele $\mathrm{T}$ at $4335 \mathrm{Da}$ corresponding to genetic variants B and A respectively at the SNP LGB_118 locusin 30 Friesian X Bunaji cows. 


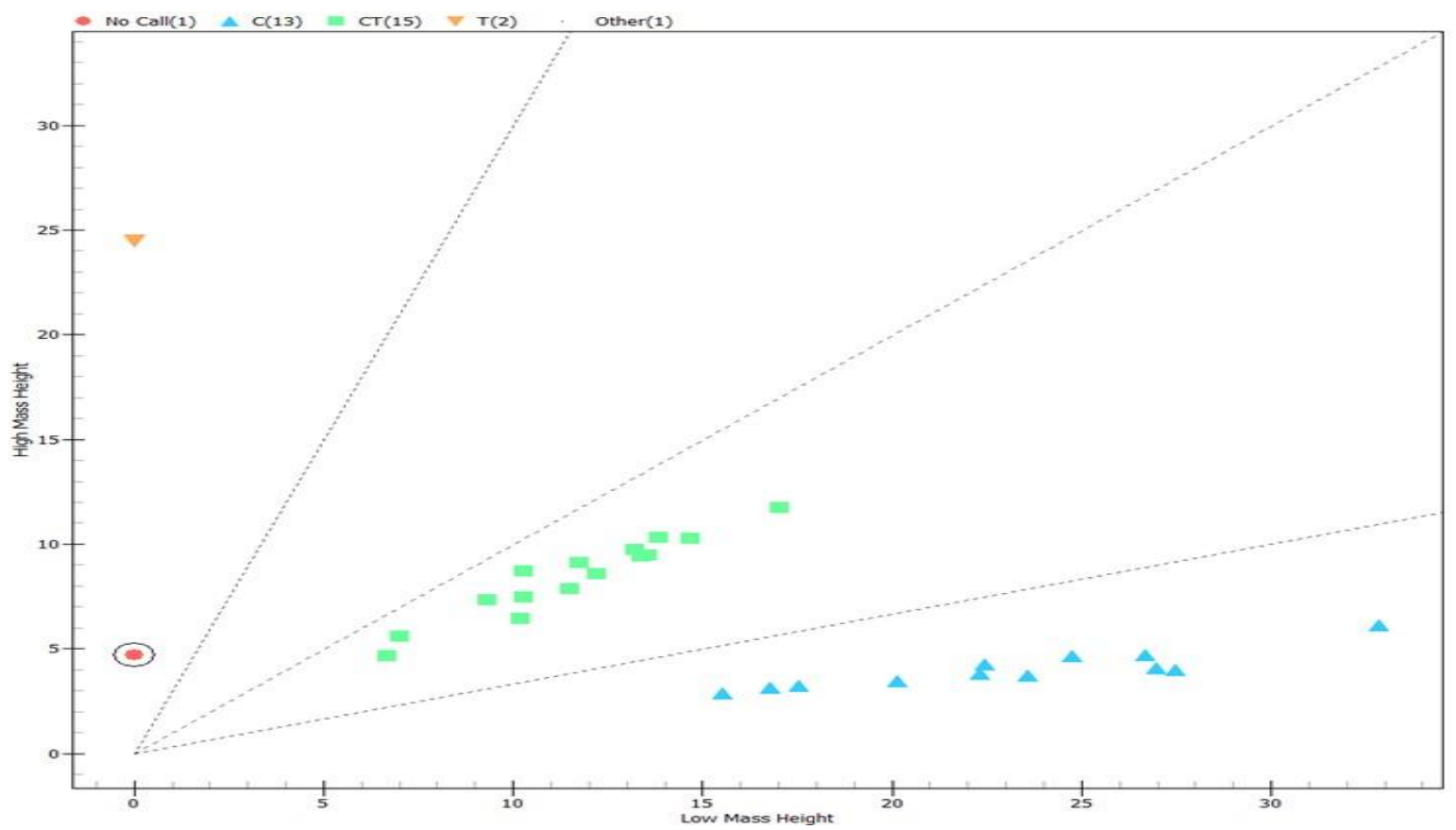

Plate 1d. The cluster plot indicated three genotypes of TT ( 2 cows), CT (15 cows) and CC (13 cows) corresponding to AA, AB, and BB respectively at the SNP LGB_118 locus in 30 Friesian X Bunaji cows.

heterozygosity, genetic variant involved, SNP call rate and Hardy- Weinberg Equilibrium (HWE) p-value for two SNPsat the beta lactoglobulin gene locus in 30 Friesian $\mathrm{X}$

B. Characteristics of Genotyping Results for two SNPs at Bunaji cows. beta lactoglobulin locus

Table 2, shows the summary characteristics that includes SNP ID, polymorphism of the SNP, observed and expected

Table 2. Characteristics of two SNPs at beta lactoglobulin gene loci assayed by iPlex mass ARRAY.

\begin{tabular}{|l|l|l|}
\hline Variables & $L G B_{-} 64$ & LGB_l18 \\
\hline Allele Number & 2 & 2 \\
Polymorphism & $\mathrm{G} / \mathrm{A}$ & $\mathrm{T} / \mathrm{C}$ \\
Genetic variants & $\mathrm{B} / \mathrm{A}$ & $\mathrm{A} / \mathrm{B}$ \\
SNP call rate & 100 & 96.67 \\
SNP genotype frequency & $\mathrm{GG}=44.8$ & $\mathrm{CC}=43.3$ \\
& $\mathrm{AG}=48.3$ & $\mathrm{CT}=50.0$ \\
SNP allele frequency & $\mathrm{AA}=6.9$ & $\mathrm{TT}=6.7$ \\
& $\mathbf{G}=69.0$ & $\mathrm{C}=68.3$ \\
Heterozygosity Observed & $\mathrm{A}=31.0$ & $\mathrm{~T}=31.7$ \\
Heterozygosity Expected & 0.483 & 0.500 \\
HWEp & 0.428 & 0.433 \\
\hline
\end{tabular}

At the $L G B \_64$ locus: The results of the current study indicated that the SNP $L G B \_64$ was polymorphic and had two alleles $A$ and $G$ with frequency 31.0 and 69.0 percent respectively corresponding to genetic variants $\mathrm{A}$ and $\mathrm{B}$ respectively. Three genotypes were identified AA, AG, and GG with frequency $6.9,48.8$ and 44.8 percent respectively corresponding to genetic variants $\mathrm{AA}, \mathrm{AB}$, and $\mathrm{BB}$ respectively. The call rate was 100 percent. The expectedheterozygosity $(0.428)$ was lower than the observed value $(0.483)$ resulting in heterozygote deficiency compared with HWE expectations. Heterozygote deficiency may be caused by certain degree of inbreeding in the population under study. A non-significant Hardy-Weinberg equilibrium P-value (0.49) was observed at the SNP LGB_64locus; this confirmed that the SNPLGB_64locus was at HWE.
At the $L G B \_118$ locus: The results of the current study indicated that the SNP $L G B \_118$ was polymorphic and had two alleles $\mathrm{T}$ and $\mathrm{C}$ with frequency 31.7 and 68.3 percent respectively corresponding to genetic variants $\mathrm{A}$ and $\mathrm{B}$ respectively. Three genotypes were identified TT, TC, and $\mathrm{CC}$ with frequency $6.7,50.0$ and 43.3 percent respectively corresponding to genetic variants $\mathrm{AA}, \mathrm{AB}$, and $\mathrm{BB}$ respectively. These results agree with previous findings in Holstein cattle [20] White Fuani and Borgou (38). The call rate was 96.67 percent. The expected heterozygosity $(0.433)$ was less than the observed value (0.500) resulting in heterozygote deficiency compared with HWE expectations. Heterozygote deficiency may be caused by certain degree of inbreeding in the population under study. A non-significant Hardy-Weinberg equilibrium P-value (0.39) was observed at 
the SNP LGB_118locus; this confirmed that the SNPLGB_118 locus was at HWE.
HWE for the most common genetic variants at the $\beta-L G$ gene locus (A and B) in 30 Friesian X Bunaji cows.

\section{Allele and Genotype frequencies of beta lactoglobulin gene in 30 Friesian X Bunaji cows}

Table 3, indicates the results of genotype and allele frequencies, and Chi-square $\left(\square^{2}\right)$ test for deviation from

Table 3.Distribution of genotype and allele frequencies of beta lactoglobulin gene in Friesian X Bunaji cows.

\begin{tabular}{|c|ccc|cc|c|}
\hline Gene & \multicolumn{4}{|l}{ Genotypic frequency (\%) } & \multicolumn{3}{c|}{ Allelic Frequency (\%) } & $\square^{2}$ (Chisquare) \\
\hline$L G B$ & AA & AB & BB & A & B & \\
& $6.7(2)$ & $50.0(15)$ & $43.3(13)$ & 31.7 & 68.3 & 0.71 NS \\
\hline
\end{tabular}

$L G B=$ beta-lactoglobulin;Note that the number of animals observed for each genotype are in brackets; $\square^{2}=$ Chi square test; $\mathrm{NS}=$ non-significant chi square

The 30 Friesian $\mathrm{X}$ Bunaji cows under this study were polymorphic and had two alleles $\mathrm{A}$ and $\mathrm{B}$. The frequencies of the alleles $\mathrm{A}$ and $\mathrm{B}$ were 68.3 and 31.7 percent respectively; allele B occurred more frequent than A. These results agree with previous studies in Holstein-Friesian x Jersey crossbred [39], Bulgarian black pied [40], Sahiwal and Tharparkar $(41,42]$, Mexican Jersey [43], Latvian Brown and Latvian Blue [44], Holstein [8,45] andCzech Fleckvieh cattle [19, $46]$ where at the $\beta$-LG gene locus variant $B$ was more common than $\mathrm{A}$. The results of the current study suggest the superiority of variant B at the beta lactoglobulin gene locus in Friesian X Bunaji cows. This is attributed to the fact that variant $\mathrm{B}$ is the reference variant at beta lactoglobulin gene locus.On the other hand, these results disagree with some previous investigations who reported that variant $A$ at the $\beta$-LG gene locus occurred more frequent than B in Romanian Simmental [47], Girolando cattle [48].

Furthermore, three genotypes homozygote AA(2 cows), heterozygote $\mathrm{AB}$ (15 cows), and homozygote $\mathrm{BB}$ (13 cows) were found with frequencies $6.7,50.0$ and 43.3 percent respectively. The most frequent genotype was $\mathrm{AB}$ (50.0 percent) followed by $\mathrm{BB}$ (43.3 percent), while the least Table 4. Means and variance $\left(\sigma^{2}\right)$ estimates of random effects and significance of fixed effects included in the analysis for milk traits in Friesian X Bunaji cows (model 1)

\begin{tabular}{|l|l|l|l|l|l|}
\hline Variable & \multirow{2}{*}{$\mathrm{N}$} & \multicolumn{3}{l|}{} & \multicolumn{2}{l|}{$\sigma^{2}$ estimates } & P-value \\
\cline { 3 - 6 } & & Mean & Cow & Residual & $\beta$-LG \\
\hline Average Daily Milk Yield (kg) & 29 & $7.52 \pm 2.49$ & 1.416 & 0.677 & $(0.01) * *$ \\
Fat $(\%)$ & 29 & $4.48 \pm 1.43$ & 0.185 & 0.348 & $(0.07) *$ \\
Protein $(\%)$ & 29 & $3.23 \pm 0.23$ & 0.004 & 0.057 & $(0.38) \mathrm{NS}$ \\
Lactose (\%) & 29 & $4.86 \pm 1.43$ & 0.135 & 2.438 & $(0.33) \mathrm{NS}$ \\
Solid-not fat (\%) & 29 & $8.78 \pm 0.78$ & 0.267 & 0.400 & $(0.67) \mathrm{NS}$ \\
Total solid (\%) & 29 & $13.23 \pm 1.58$ & 0.000 & 1.926 & $(0.26) \mathrm{NS}$ \\
Salts $(\%)$ & 29 & $0.73 \pm 0.05$ & 1.460 & 0.003 & $(0.34) \mathrm{NS}$ \\
Milk-pH & 29 & $6.67 \pm 0.08$ & 0.007 & 0.009 & $(0.47) \mathrm{NS}$ \\
\hline
\end{tabular}

$\mathrm{M}-\mathrm{pH}=\mathrm{pH}$ of milk; $\beta$-LG $=$ beta-lactoglobulin; * = Fixed effect is significant at $\mathrm{P} \leq 0.05 ; * *=$ Fixed effect is significant at $\mathrm{P} \leq$ $0.01 ; \mathrm{NS}=$ Fixed effect is not significant at $\mathrm{P}>0.05$.

The results of this studyshowed that the estimates of variance within the cow were higher than the variance between the cows (within the beta lactoglobulin genotypes) for daily milk yield and contents of salts; whereas, contents of fat, protein, lactose, solid-not fat, and total solid indicated lower variance estimates within the cow than between the cows (within the beta lactoglobulin genotypes). Besides that, the content of milk total solid indicated zero variance estimate for the cow.

The means recorded in this study were daily milk yield $(7.52 \pm 2.49 \mathrm{~kg} / \mathrm{cow} / \mathrm{day})$, contents of fat $(4.48 \pm 1.43$ percent $)$, common was AA (6.9 percent) in the 30 Friesian X Bunaji cows. These results support the previous findings in Holstein-Friesian x Jersey crossbred [39], Bulgarian black pied [40], Sahiwal and Tharparkar (41, 42], Holstein [8, 45], and Czech Fleckvieh cattle $[19,46]$ where at the beta lactoglobulin gene locus genotype $\mathrm{AB}$ was the most frequent followed by $\mathrm{BB}$. This is attributed to the fact that most selection program favoured the $\mathrm{AB}$ and $\mathrm{BB}$ genotypes which influenced milk yields or production in dairy cattle. On the contrary to the current results, some authors found that at the beta lactoglobulin gene locus genotype $\mathrm{BB}$ was the most frequent in Sahiwal and Tharparkar [41,42], Mexican Jersey [43], Latvian Brown and Latvian Blue, [44] and Holstein cattle $[8,45]$.

The result of chi-square test $\left(\chi_{2}\right)$ was non-significant $(0.71)$ and indicated that the Friesian X Bunaji cows were in HW equilibrium at the $L G B$ gene locus in Friesian X Bunaji cows.

\section{Summary statistics for the random and fixed effects}

Table 4, shows the means and variance component estimates for the milk yield, milk $\mathrm{pH}$ and milk composition traits and significant of fixed effect ( $\beta$-LG genotypes) in Model 1. protein (3.23 \pm 0.23 percent), lactose $(4.86 \pm 1.43$ percent $)$, solid-not fat $(8.78 \pm 0.78$ percent $)$ total solid $(13.23 \pm 1.58$ percent $)$ and salts $(0.73 \pm 0.05$ percent $)$ in milk and the milk pH $(6.67 \pm 0.08)$. These values are in line with previous reports [30] and meet the suggested standard conditions for cow's milk components [49]. The $\mathrm{pH}$ ranged of $6.5-6.7$ reported in this study for cow milk indicated that the cows were free from bacterial contamination or mastitis [49]. 
E. Effects of Beta-lactoglobulin $(\beta-L G / L G B)$ genotypes on milk yield, $\mathrm{pH}$, and composition traits.

Table 5, represents the least square means and standard deviation of contents of daily milk yield, milk $\mathrm{pH}$, contents of

Table 5. Effects of beta lactoglobulin genotypes on milk yield, $\mathrm{pH}$, and composition traits in Friesian X Bunaji cows

\begin{tabular}{|c|c|c|c|c|}
\hline & \multicolumn{4}{|c|}{$\beta$-LG (Beta lactoglobulin) } \\
\hline Variable $(\%)$ & $\mathrm{AA}$ & $\mathrm{AB}$ & BB & $\mathrm{P}$-value \\
\hline No of cows & 2 & 15 & 13 & \\
\hline ADMY & $9.13 \pm 1.07^{\mathrm{a}}$ & $7.61 \pm 0.51^{\mathrm{ab}}$ & $6.07 \pm 0.53^{\mathrm{c}}$ & $(0.01) * *$ \\
\hline Milk pH & $6.61 \pm 0.07$ & $6.69 \pm 0.03$ & $6.71 \pm 0.04$ & $(0.47) \mathrm{NS}$ \\
\hline Fat & $4.37 \pm 0.61^{\mathrm{b}}$ & $4.28 \pm 0.29^{b}$ & $5.29 \pm 0.30^{\mathrm{a}}$ & $(0.05) *$ \\
\hline Protein & $3.34 \pm 0.19$ & $3.10 \pm 0.09$ & $3.21 \pm 0.10$ & $(0.38) \mathrm{NS}$ \\
\hline Lactose & $5.05 \pm 0.29$ & $4.66 \pm 0.14$ & $4.83 \pm 0.14$ & $(0.33) \mathrm{NS}$ \\
\hline Solid-not fat & $8.26 \pm 0.64$ & $8.48 \pm 0.31$ & $8.74 \pm 0.32$ & $(0.67) \mathrm{NS}$ \\
\hline Total solid & $13.69 \pm 1.09$ & $12.89 \pm 0.52$ & $13.85 \pm 0.54$ & $(0.26) \mathrm{NS}$ \\
\hline Salts & $0.75 \pm 0.04$ & $0.70 \pm 0.02$ & $0.72 \pm 0.02$ & $(0.34) \mathrm{NS}$ \\
\hline
\end{tabular}

$*=\beta$-LG genotypes are significant at $\mathrm{P} \leq 0.05 ; * *=\beta$-LG genotypes are significant at $\mathrm{P} \leq 0.01 ; \mathrm{NS}=\beta$-LG genotypes are not significant at $\mathrm{P}>0.05 ; \mathrm{abc}=$ Means with different superscript across roll differ significantly.

The findings of the current study, showed that the $\beta-L G$ genotypes (AA, AB, and BB)significantlyaffected daily milk yield $(\mathrm{P}<0.01)$, and content of milk fat $(\mathrm{P}<0.05)$ but there were non-significant effects on milk $\mathrm{pH}$, contents of protein, lactose, solid-not fat, total solid and salts in milk. The cows carrying homozygote AAgenotype produced the highest amount of milk per day $(9.13 \pm 1.07 \mathrm{~kg} / \mathrm{cow} /$ day $)$ followed by those carrying AB genotype $(7.61 \pm 0.51 \mathrm{~kg} / \mathrm{cow} /$ day) though there were not statistically different while those with genotype $\mathrm{BB}$ produced the least amount of milk; the ranking for daily milk yield was $\mathrm{AA}=\mathrm{AB}>\mathrm{BB}$. Additionally, the cows carrying genotype $\mathrm{BB}$ produced milk with the highest fat content (5.29 \pm 0.30 percent); the cows carrying genotype $\mathrm{AB}$ produced milk with the least fat content (4.28 \pm 0.29 percent); ranking recorded for content of fat was $\mathrm{BB}>\mathrm{AA}=\mathrm{AB}$. These result support the report of Piątkowskaet al. [50] who indicated that $B L G$ genotypes $\mathrm{AA}, \mathrm{AB}$, and $\mathrm{BB}$ had significant $(\mathrm{P}<0.05)$ relationship with the milk traits in Holstein Frisian cattle; cows with $B L G$ genotype AA produced the highest amount of milk compared to those carrying $\mathrm{AB}$ and $\mathrm{BB}$ genotypes $(\mathrm{AA}>\mathrm{AB}>\mathrm{BB})$ while those with $\mathrm{BB}$ genotype produced milk with the highest content of fat $(\mathrm{BB}>\mathrm{AA}=\mathrm{AB})$. Likewise, Wageh Zaglool et al., (8) working with Holstein Friesian cows at the $L G B$ locus found that cows carrying genotype AA indicated higher milk yield while those carrying the BB genotype, had higher content of fat than those with genotypes AA and AB.Similarly, Ren et al. [50] indicated that the $\mathrm{BB}$ genotype at the $L B G$ locus correlated with higher contents of fat in milk, which are good properties for processing and milk quality improvement. According to the findings of Neamt et al. [47], the $A A$ genotype of LGB gene related with higher milk production than $B B$.This is may be attributed to differences in the isoelectric point and molecular weight of the various variants. On the contrary with respect to yields of milk, Alim et al. [20] reported that in Chinese Holstein cattle at the LGB gene locus, the cows carrying genotype TT(BB) produced milk with the highest 305 day milk yield, fat yield and protein yield compared with $\mathrm{CC}(\mathrm{AA})$ cows; $\mathrm{CT}(\mathrm{AB})$ cows were at the middle position. In the same way, Hristov et al. [26] reported that at the $L G B$ locus, cows carrying the genotype $\mathrm{BB}$ influenced higher milk yield. milk fat, protein, lactose, solid-not fat, total solid, and salts for beta-lactoglobulin genotypes (AA, AB, and $\mathrm{BB}$ ) in Friesian X Bunaji cows.

\section{政}

Recently, the beta-lactoglobulin polymorphism has attracted interest among researchers, milk producers and consumers because of the possible association between certaingenetic variants and milk traits and technological properties of milk. It might be concluded that the Friesian X Bunaji cows produce milk that meet the recommended standard for contents of milk fat, protein, solid-not fat, total solid and milk $\mathrm{pH}$ for cow's milk. The beta lactoglobulin allele B is more frequent in the population of Frieisian $\mathrm{X}$ Bunaji cows. The cows carrying the beta lactoglobulin genotypes $\mathrm{AA}$ and $\mathrm{AB}$ produce the highest amount of milk per day per cow, while those cows carrying genotype $\mathrm{BB}$ produce milk with the highest amount of fat content. The LGB gene could be a useful marker for selection of cattle in favour of milk production. Considering the association of beta lactoglobulin variants with processing properties and most of the produced is used for yoghurt production; it is recommended that the effects of beta lactoglobulin genotype on yoghurt parameters be investigated.

\section{REFERENCES}

[1] Archana, V. (2013). Nucleotide sequence variability in exon 4 of prolactin locus in Murrah buffaloes (Bubalusbubalis). Research Journal of Biotechnology, 8(6):61-65.

[2] Wakchaure, R., Ganguly, S., Parveez, A. Para., Praveen,K., and Qadri K. (2015): Molecular markers and their applications in farm animals: $a$ review. International Journal of Recent Biotechnology, 85(9), 2368-75.

[3] Teneva, A. and Petrovic, M. (2010): Application of molecular markers in livestock improvement. Biotechnology in Animal Husbandry, 26(3-4): 135-154.

[4] Oikonomou, G., Michailidis, G., Kougioumtzis, A., Avdi, M. and Banos, G. (2011). Effect of polymorphisms at the STAT5A and FGF2 gene loci on reproduction, milk yield and lameness of Holstein cows. Research Veterinary science, 91: 235-239.

[5] Kharrati Hamed Koopaee and Ali Esmailizadeh Koshkoiyeh. (2014) SNPs genotyping Technologies and Their Applications in Farm Animals Breeding Programs: Review. Brazilian Archives of Biology and Technology, 57 (1): 87-95.

[6] Reinhardt, T. A., Lippolis, J. D., and Sacco, R. E. (2012). Bovine milk exosome proteome. Journal of Poteome research, 75(5), 1486-1486.

[7] Dziuba B, and Dziuba M. (2014). Milk proteins-derived bioactive peptides in dairy products: Molecular, biological, and methodological aspects. Acta Scientarum Polononum Technologia Alimentaria13:5-25. 
[8] Wageh Zaglool A, Awad A, El sayed El Araby I and Mohamed El-Bayomi Kh. (2016). Association of $\beta$-Lactoglobulin Gene Polymorphism with Milk Yield, Fat and Protein in Holstein-Friesian Cattle. World's Veterinary Journal. 6(3): 117-122.

[9] Zaibet, L., Traore, S., Ayantunde, A., Marshall, K., Johnson, N. and Siegmund-Schultze, M. (2011). Livelihood strategies in endemic livestock production systems in sub-humid zones of West Africa: trends, trade-offs, and implications. Environmental Development and Sustainability, 13:87-105.

[10] Kebebe, E.G., Oosting, S.J., Baltenweck, I. and Duncan, A.J. (2017) Characterisation of adopters and non-adopters of dairy technologies in Ethiopia and Kenya. Tropical Animal Health and Production, 49:681-690.

[11] Miranda, Guy Leonardo Bianchi, Zuzana Krupova, Philippe Trossat, and Patrice Martina. (2020) An improved LC-MS method to profile molecular diversity and quantify the six main bovine milk proteins, including genetic and splicing variants as well as post-translationally modified isoforms. Journals Elsevier Food Chemistry X5100080: 1-12.

[12] Rachagani S, Gupta ID, Gupta N, Gupta SC (2006). Genotyping of beta-lactoglobulin gene by PCR-RFLP in Sahiwal and Tharparkar cattle breeds. BMC Genetic 7: 31-34.

[13] Kusza S, Sziszkosz N, Nagy K, Masala A, Kukovics S and Andras J (2015). Preliminary result of a genetic polymorphism of $\beta$-lactoglobulin gene and the phylogenetic study of ten Balkan and central European indigenous sheep breeds. Acta Biochimica Polonica, 62:109-112.

[14] Farrell, H. M., Jr Jimenez-Flores, R., Bleck, G. T., Brown, E. M., Butler, J. E., and Creamer, L. K. (2004). Nomenclature of the proteins of cows' milk-sixth revision. Journal of Dairy Science, 87, 1641-1674.

[15] Fox, P. F., Uniacke-Lowe, T., MCSweeney, F. P., and O"Mahony, J. A (2015). Dairy chemistry and biochemistry. New York (USA): Springer International Publishing.

[16] Gupta, C., and Prakash, D. (2017). Therapeutic Potential of Milk Whey. Beverages, 3(3): 31.

[17] Braunitzer, G. and B. R. Chen, 1972. Die Spaltung des $\beta$-lactoglobulins AB mit Bromecyan. HoppeSeyler's Z. Physiol. Chem.,353: 832.

[18] Aschaffenburg R. and Drewry J. (1955). Occurrence of different beta-lactoglobulins in cow's milk. Nature, 176: 218-219.

[19] Caroli, A. M., Chessa, S. and Erhardt, G. J. (2009). Invited review: milk protein polymorphisms in cattle: effect on animal breeding and human nutrition. Journal of Dairy Science, 92 (11): 5335-5352.

[20] Gallinat J. L., S. Qanbari, C. Drögemüller, E. C. G. Pimentel, G. Thaller, and J. Tetens (2013). DNA-based identification of novel bovine casein gene variants. Journal of Dairy Science, $96: 699-709$.

[21] Sawyer, L. (2003) Beta-lactoglobulin. In Advanced dairy chemistry (Fox, P. F., and McSweeney, P. L. H. eds.), Kluwer Academic/Plenum Publishers, Amsterdam, The Netherland. 319-386.

[22] McSweeney, P. L. H., and Fox P.F. (2013). Advanced Dairy Chemistry (Vol. 1A). London.

[23] Hill JP (1993). The relationship between $\beta$-lactoglobulin phenotype and milk composition in New Zealand dairy cattle. Journal of Dairy Science 76: 281-286.

[24] Selvaggi, M., Laudadio, V., Dario, C. and Tufarelli, V. (2014). Investigating the genetic polymorphism of sheep milk proteins: a useful tool for dairy production. Journal of Science Food Agriculture, (94) 15: 3090-3099.

[25] Singh U, Deb R, Kumar S, Singh R, Sengar G and Sharma A (2014). Association of prolactin and beta-lactoglobulin genes with milk production traits and somatic cell count among Indian Frieswal (HF $\times$ Sahiwal) cows. Biomarkers and Genomic Medicine, 7 (1):38-42.

[26] Hristov, P., Teofanova, D., Mehandzhiyski, I., Zagorchev, L., and Radoslavov, G. (2013). Significance of Milk protein genes polymorphism for Bulgarian Rhodopean cattle: comparative studies. Biotechnology and Biotechnological Equiptment, 27(2), 3659-3664.

[27] Gradinaru, A.C.; Ilie, D.E.; Creanga, S. (2013). Milk protein genetic variants in Romanian Spotted, Holstein Friesian and Montbéliarde cows and some correlations with milk parameters. Res. J. Biotechnol., 8, 3-9.

[28] Čítek Jindřich, Michaela Brzáková, Lenka Hanusová, Oto Hanuš, Libor Večerek, Eva Samková, Zuzana Křížová. Irena Hoštičková, Tereza Kávová, Karolina Straková, and Lucie Hasoňová (2020). Gene polymorphisms influencing on yield, composition, and technological properties of milk from Czech Simmental and Holstein cows. Asian-Australas Journal of Animal Science 00 (00): 14-22.

[29] Alim, M. A. Dongxiao Sun, Yi Zhang, Yuan Zhang, Qin Zhang and Lin Liu (2015). DNA Polymorphisms in the $\beta$-lactoglobulin and $\kappa$-casein Genes Associated with Milk Production Traits in Dairy Cattle. Bioresearch Communications (1)2: 82-86
[30] Alphonsus, C, Essien) IC, Akpa, GN. and Barje2 PP. (2010). Factors Influencing Milk Yield Characteristics in Bunaji and Friesian x Bunaji Cows in Northern Nigeria. Animal Production 13(3):143-149.

[31] Roschinsky, R., Kluszczynska, M., Sölkner, J., Puskur, R. \&Wurzinger, M. (2015). Smallholder experiences with dairy cattle crossbreeding in the tropics: from introduction to impact. Animal, 9(1), 150-157.

[32] Google Earth, (2012). Google Earth @ 2011 Digital Globe.

[33] Tanko, R.J., Kallah, M. S., Adamu, A. M., Lakpini, C. A. M. and Adeyinka, I.A. (2014). Weight Responses of Bunaji Cattle Grazing Native Rangelands Strip-Sown to Three Different Forage Legumes in the Northern Guinea Savanna of Nigeria. Journal of Animal Production Research 26:90-98.

[34] Gabriel S, Ziaugra L, Tabbaa D. (2009) SNP genotyping using the Sequenom MassARRAY iPLEX platform. Current Protocol Human Genetics, 60(1):2-12.

[35] Ketto, I. A., Knutsen, T. M., Øyaas, J., Heringstad, B., Ådnøy, T., Devold, T. G. \& Skeie, S. B. (2017). Effects of milk protein polymorphism and composition, casein micelle size and salt distribution on the milk coagulation properties in Norwegian Red cattle. International Dairy Journal, 70: 55-64.

[36] SAS, (2002). Statistical Analysis System, Version 9.0 SAS Institute Inc. Cary North Carolina, USA.

[37] Kramer, C.Y. (1956). Extension of Multiple Range Tests to Group Means with Unequal Numbers of Replications. Biometrics, 12: 309-310.

[38] Houaga Isidore, Anne W.T. Muigai, Chakirath F.A. Salifou, Souradjou O.G. Idrissou, Kévin S. Kassa, Souley Sidi, Emmanuel Hogbonouto, Chabi T.S.R. Biobou and Issaka A.K. Youssao (2018). Effect of Herd, Age, Parity and Stage of Lactation on Milk Production Traits in Indigenous Borgou Cattle Breed in Benin. International Journal of Advanced Research 6(5): 92-100.

[39] Berry SD, N Lopez-Villalobos, EM Beattie, SR Davis, LF Adams, NL Thomas, AE Ankersmit-Udy, AM Stanfi eld, K Lehnert, HE Ward, JA Arias, RJ Spelman, and RG Snell. (2010). Mapping a quantitative trait locus for the concentration of $\beta$-lactoglobulin in milk, and the effect of $\beta$-lactoglobulin genetic variants on the composition of milk from Holstein-Friesian x Jersey crossbred cows. New Zealand Veterinary Journal 58(1): 1-5

[40] Hristov P, Teofanova D, Mehandzhiyski I, Yoveva A, and Radoslavov G (2012) Genotyping of Endemic for Rhodopa Mountains Shorthorn Rhodopean Cow Breed. Biotechnology and Biotechnological Equipment 26: 12-15.

[41] Kishore A, Mukesh M, Sobti RC, Keviletsu K, Mishra BP, and Sodhi M (2014). Single Nucleotide Polymorphism in Exon 4 and Promoter Regions of $\beta$ - Lactoglobulin Gene in Native Cattle (Bosindicus) Breeds of India. Journal of Advanced Dairy Research, 2 (3):135-131.

[42] Mir S N, Ullah O and Sheikh R (2014). Genetic polymorphism of milk protein variants and their association studies with milk yield in Sahiwa cattle. African Journal of Biotechnology, 13(4): 555-565.

[43] Zepeda-Batista José Luis, Baldomero Alarcón-Zúñiga, Agustín Ruíz-Flores, Rafael Núñez-Domínguez, Rodolfo Ramírez-Valverde (2015). Polymorphism of three milk protein genes in Mexican Jersey cattle. Electronic Journal of Biotechnology, 18: 1-4

[44] [44]. Petrovska, SolvitaDaina Jonkus, Jelena Zagorska, Inga Ciprovica (2017). The Influence of Kappa-Casein and Beta-Lactoglobulin Genotypes on Milk Coagulation Properties in Latvia Dairy Breed. Agricultural Sciences (Crop Sciences, Animal Sciences), $3: 75-80$.

[45] Soyudal B., S. Ardicli, H. Samli, D. Dincel, F. Balci (2018). Association of polymorphisms in the CSN2,CSN3, LGB and $L A L B A$ genes with milk production traits in Holstein cows raised in Turkey. Journal of Hellenic Veterinary Medical Society 69(4): 1271-1282.

[46] Kyselová Jitka, Kateřina Ječmínková, Jitka Matějíčková, Oto Hanuš, Tomáš Kott, Miloslava Štípková, and Michaela Krejčová. (2019). Physiochemical characteristics and fermentation ability of milk from Czech Fleckvieh cows are related to genetic polymorphisms of $\beta$-casein, $\kappa$-casein, and $\beta$-lactoglobulin. Asian-Australas Journal Animal Science, 32: 14-22.

[47] Neamt, Radu Ionel ., Gheorghe Saplacan--, Stelian Acatincai , Ludovic Toma Cziszter, Dinu Gavojdian, Daniela Elena Ilie (2017). The influence of CSN3 and LGB polymorphism on milk production and chemical composition in Romanian Simmental cattle. Acta Biochimica Polonica, 64(3): 493-497.

[48] Barbosa, Severino Benone Paes, Araújo, Ítala Iara Medeiros de, Martins, Marta Fonseca, Silva, Elizabete Cristina da, Jacopini, Laís Aberrachid, Batista, Ângela Maria Vieira; Silva, Marcus Vinícius Barbosa da (2019). Genetic association of variations in the 
kappa-casein and $\beta$-lactoglobulin genes with milk traits in girolando cattle. Revista Brasileira de Saúde $e$ Produção Animal., 20: 1 -12.

[49] Anantakrishnan, C. P., Khan, A. Q. and Padmanabhan, P. N. 1993. The Technology of Milk Processing, Shri Lakshmi Publications, Kilpauk, Madras: 1-25.

[50] Piątkowska CE, Szewczuk M, Olszewska A and Chociłowicz E (2011). Association between beta-lactoglobulin (lgb) polymorphism and yield and composition of milk of Holstein Friesian cows imported from Sweden, Acta Scientiarum Polonorum Zootechnica, 10 (1): 9-18.

[51] Ren, D.X., Miao, S.Y., Chen, Y.L., Zou, C.X., Liang, X.W. and Liu, J.X. (2011). Genotyping of the k-casein and $\beta$-lactoglobulin genes in Chinese Holstein, Jersey, and water Buffalo by PCR-RFLP. Journal of Genetics, 90:1-5. 